\title{
EKSPLORASI RIZOBAKTERI INDIGENOUS DAN UJI ANTAGONIS TERHADAP PATOGEN Rigidosporus microporus DAN Phellinus noxius PADA TANAMAN KARET (Hevea brasiliensis) SECARA IN VITRO \\ (Exploration of Indigenous Rizobacteria and Antagonistic Test against Patogen Rigidoporus microporus And Phellinus noxius In Rubber Plant (Hevea brasiliensis) In Vitro)
}

\author{
Murtadha $^{1}$, M. Abduh Ulim ${ }^{1}$, Syamsuddin ${ }^{1 *}$ \\ ${ }^{1}$ Program Studi Agroteknologi, Fakultas Pertanian, Universitas Syiah Kuala
}

\begin{abstract}
Abstrak. Penelitian bertujuaan untuk mendapatkan isolat rizobakteri yang mampu berperan sebagai agens biokontrol terhadap pengendalian patogen $R$. microporus dan $P$. noxius secara in vitro serta sebagai agen rizobakteri pemacu pertumbuhan tanaman (RPPT). Penelitian dilaksanakan di Laboratorium Ilmu dan Teknologi Benih Jurusan Agroteknologi, Fakultas Pertanian, Universitas Syiah Kuala, Darussalam Banda Aceh, mulai Oktober sampai Desember 2017. Penelitian ini menggunakan Rancangan Acak Lengkap non faktorial. Faktor yang diteliti yaitu isolat rizobakteri, taraf yang dicobakan terdiri dari 15 isolat dan dua patogen antagonis $R$. microporus dan $P$. noxius, yang diulang sebanyak 3 kali sehingga terdapat 90 unit satuan percobaan. Hasil penelitian menunujukkan isolat rizobakteri mampu menekan pertumbuhan koloni cendawan patogen. Pada patogen uji $R$. microporus terdapat 3 rizobakteri yang paling baik yaitu isolat DLG5/3 dengan persentase penghambatan 68,33\%, DLG4/1 dengan persentase penghambatan 66,66\% dan DLG4/7 dengan persentase penghambatan 63,33\%. Pada patogen uji P.noxius terdapat dua rizobakteri yang paling baik dalam menghambat pertumbuhan koloni cendawan patogen yaitu isolat DLG5/1 dengan persentase penghambatan $60,33 \%$, dan DKP6/3 dengan persentase penghambatan $52,50 \%$. Pada laju penghambatan isolat rizobakteri yang paling baik pada patogen $R$. microporus yaitu isolat DLG6/4 dan DKP4/1 dengan nilai rerata laju penghambatan 20,33 $\mathrm{mm} /$ hari. Pada patogen $P$. noxius menunjukan isolat rizobakteri yang paling baik yaitu isolat DLG4/1 dengan nilai laju penghambatan $12,05 \mathrm{~mm} / \mathrm{hari}$.
\end{abstract}

Kata kunci : Rizobakteri, Uji Antagonis, $R$ microporus, P noxius, Tanaman Karet.

\begin{abstract}
The research was conducted to obtain rhizobacteria isolates capable of acting as biocontrol agents on pathogen control of $R$. microporus and P. noxius in vitro and as plant growth promoter rhizobacteria (PGPR). The research was conducted at the Science and Technology of seed Laboratory, Department of Agrotechnology, Faculty of Agriculture, Syiah Kuala University, Darussalam Banda Aceh, starts from October to December 2017. The research using Completely Randomized Design non factorial. Factors researched were rhizobacteria isolates, the experimental stage consisted of 15 isolates and 2 antagonist were $R$. microporus dan P. noxius, and 3 time repeated until be found 90 units of treatment. The results showed that rhizobacteria isolates capable to inhibith growth of colonies pathogenic. In the pathogen of $R$. microporus test, there are 3 better rhizobacteria were DLG5/3 isolate with $68.33 \%$ inhibition percentage, DLG4/1 with $66.66 \%$ inhibition percentage and DLG4/7 with $63,33 \%$ inhibition percentage. In the pathogen of $P$. noxius there are 2 best rhizobacteria inhibiting growth, DLG5/1 isolate with $60.33 \%$ inhibition percentage, and DKP6/3 with 52,50\% inhibition percentage. In the pathogen of $R$. microporus test, there are 2 better rhizobacteria were DLG6/4 and DKP4/1 with 20,33 $\mathrm{mm} /$ day inhibition percentage. In the pathogen of $P$. noxius test, the best rhizobacteria were DLG4/1 with 12,05 $\mathrm{mm} /$ day inhibition percentage.
\end{abstract}

Keywords: Rhizobacteria, Antagonis Test, $R$ microporus, P noxius, Rubber Plant,

\section{PENDAHULUAN}

Tanamn karet (Hevea brasiliensis) merupakan salah satu komoditi perkebunan penting, baik sebagai sumber devisa, sumber pendapatan maupun kesempatan kerja. Pendorong pertumbuhan ekonomi sentra-sentra baru di wilayah sekitar perkebunan karet serat maupun pelestarian lingkungan dan sumberdaya hayati. Perkebunan karet terluas di dunia terdapat di Indonesia dengan luar areal yang di memiliki yaitu sekitar 3.6 juta ha, yang meliputi $84.94 \%$ perkebunan rakyat, $6.36 \%$ perkebunan negara dan $8.71 \%$ perkebunan swasta. Sumatera menjadi wilayah dengan perkebunan karet terluas di Indonesia yaitu $70 \%$, 
kemudian Kalimantan 20\%, diikuti Jawa 5\%, dan lain-lainnya 5\% (Direktorat Jenderal Perkebunan, 2016). Namun demikian produktivitas karet di Indonesia tergolong relatif rendah. Perkebunan negara produktivitasnya $1.433 \mathrm{~kg} \mathrm{ha}^{-1}$ tahun $^{-1}$, perkebunan swasta 1.491 $\mathrm{kg} \mathrm{ha}{ }^{-1}$ tahun $^{-1}$ dan perkebunan rakyat hanya $981 \mathrm{~kg} \mathrm{ha}^{-1}$ tahun $^{-1}$ (Direktorat Jenderal Perkebunan, 2016). Rendahnya produktivitas karet salah satunya disebabkan oleh serangan penyakit tanaman (Siagian, 1995).

Rigidoporus microporus merupakan salah satu jamur pembawa penyakit pada tanaman karet. Jamur akar putih (JAP) dapat menyerang tanaman karet di pembibitan, masa penyambungan entres, tanaman belum menghasilkan (TBM), dan tanaman menghasilkan (TM) melalui perakaran (Situmorang et al., 2007). JAP menyebabkan kematian tanaman karet dengan cara melapukkan akar dan leher akar. Jamur akar putih diprediksikan menimbulkan kematian pada perkebunan besar 3.0\% dan pada perkebunan rakyat 5.0\% di Indonesia dengan perkiraan nilai kerugian sampai 300 milliar per tahun (Situmorang, 2004).

Jamur akar coklat (Phellinus noxius) (Corner) G. H. Cunn. adalah penyebab penyakit jamur akar cokelat (JAC) pada tanaman berkayu di seluruh kawasan Pasifik dan Asia Tenggara. Jamur ini dapat menyerang lebih dari 200 jenis pohon diantaranya pinus, pala, karet, mahogani, kopi, dan kakao. Tanaman yang terserang mengalami kemunduran pertumbuhan, dan pada serangan berat dapat menyebabkan kematian tanaman. Jamur akar coklat sangat sulit dideteksi sejak dini, seringkali diketahui serangan yang terlihat di lapangan sudah termasuk ke tahah yang parah yaitu daun mulai menguning, layu dan mudah rontok, serta akarnya menjadi membusuk, kering, rapuh dan mudah hancur. Akar yang terinfeksi JAC terlihat membesar dan diselimuti oleh butiran pasir dan tanah yang menempel sangat kuat, permukaan akar akan ditemukan rizomorf, pada kayu yang terifeksi tumbuh garis-garis coklat yang terdiri dari miselium (Semangun, 2000, Supriadi et al., 2004, Brooks et al., 2007).

Pengendalian secara hayati patogen JAP dan JAC menggunakan agens biokontrol dari hasil penelitian terakhir memberikan hasil yang sangat efektif. Hasil penelitian lapangan penggunaan agens hayati Pseudomonas fluorescens dan Bacillus sp efektif mengendalikan penyakit JAP dan JAC tanaman karet di daerah endemik penyakit (Nasrun et al., 2012).

Gao, et al. (2010) menyatakan Mekanisme rizobakteri dalam menjaga tanaman dari serangan patogen ada lima cara yaitu: (1) menghasilkan enzim litik dan senyawa antibiotik dalam menghambat perkembangan dan pertumbuhan patogen secara langsung; (2) melalui perangsangan endofit terhadap tanaman serta pembentukan metabolit sekunder dalam menghambat secara tidak langsung; (3) merangsang tanaman agar tumbuh lebih tahan dari sifat agresif patogen; (4) menyulitkan patogen melakukan penetrasi dengan cara kolonisasi jaringan tanaman; dan (5) hiperparasit.

\section{METODE PENELITIAN}

Penelitian ini Telah dilaksanakan di Laboratorium Ilmu dan Teknologi Benih Program Studi Agroteknologi, Fakultas Pertanian, Universitas Syiah Kuala, Darussalam Banda Aceh.

\section{MATERI DAN METODE}

\section{Alat dan Bahan}

Alat yang digunakan dalam penelitian ini yaitu Laminar air flow, incubator, autoclave, mixer, erlenmeyer, alumunium foil, gelas ukur, tabung reaksi, rak tabung reaksi, mikroskop, cork borrer, vortex, timbangan analitik, jarum ose, pipet ukur, lampu bunsen, cawan petri, oven, cangkul, sekop, ayakan 9 mesh, pulpen. Bahan yang digunakan yaitu tanah dari rizosfer tanaman karet, media NA (Nutrient Agar), PDA (Potato Dextrose Agar), chloram-phenicol,

Eksplorasi Rizobakteri Indigenous Dan Uji Antagonis Terhadap Patogen Rigidoporus microporus Dan Phellinus noxius Pada Tanaman Karet (Hevea brasiliensis) Secara In Vitro (Murtadha, M. Abduh Ulim, 
asam laktat, natrium hipoklorit, kapas, alkohol, spiritus, plastik tahan panas, kertas lebel dan aquadest.

\section{Metode Penelitian}

Rancangan yang akan digunakan dalam penelitian ini ada 2 metode, yaitu metode eksploratif deskriptif dan metode eksperimen. Metode eksploratif deskriptif adalah metode yang digunakan untuk mengisolasi patogen dan mengisolasi rizobakteri kandidat agens biokontrol. Metode eksperimen yaitu uji antagonisme beberapa rizobakteri hasil isolasi dengan patogen tanaman karet pada media PDA secara in vitro. Rancangan yang digunakan pada uji antagonisme rizobakteri dengan patogen adalah Rancangan Acak Lengkap (RAL) non faktorial. Faktor yang diteliti yaitu isolat rizobakteri, taraf yang dicobakan terdiri dari 15 isolat dan dua patogen antagonis $R$. microporus dan $P$. Noxius yang diulang sebanyak 3 kali sehingga terdapat 90 unit satuan percobaan, rizobakteri yang diperoleh diberi simbol $\mathrm{R}$ dan patogen diberi simbol P.

\section{Pelaksanaan Penelitian}

\section{Deteksi, Isolasi dan Identifikasi Patogen Penyebab Penyakit pada Tanaman Karet di Lapangan}

Pendeteksian dan identifikasi patogen penyakit tanaman karet berdasarkan hasil pengamatan perkembangan penyakit di perkebunan karet rakyat, desa Lango dan Desa Kuta Padang Kecamatan Pante Ceuremen Kabupaten Aceh Barat. Berdasarkan hasil survei dapat diketahui jenis penyakit dan patogen yang berkembang pada area perkebunan karet kemudian ditentukan dan diambil isolat patogen melalui pengambilan bagian akar tanaman karet yang terinfeksi penyakit JAP dan JAC. Isolasi menggunakan medium Potato Dextrose Agar (PDA). Isolasi bagian tanaman karet yang terinfeksi penyakit JAP dan JAC dilakukan dengan metode yang dipakai di Balai Penelitian Karet Getas. Akar yang terinfeksi penyakit JAP dan JAC dicuci dengan air bersih, disterilkan dengan nantrium hipoklorit $2 \%$ selama 5 menit sebagai desinfektan untuk mengurangi kontaminasi mikroorganisme lain, dibilas dengan aquadest steril, dipotong secara aseptik dengan pisau menjadi potongan-potongan kecil dengan ukuran $1 \mathrm{~cm}$, dan diletakkan di atas media PDA dalam cawan petri yang diberi 1 tetes asam laktat $25 \%$, dan diinkubasi selama \pm 7 hari pada ruang bersuhu 26-29 0C dengan penyinaran NUV 12 jam terang dan 12 jam gelap. Pengamatan dilakukan pada 7 hari setelah inkubasi (HSI). Identifikasi dilakukan berdasarkan pengamatan makroskopik karakter kultur (Agarwal dan Sinclair 1987; Diekmann 1993). Koloni masing-masing patogen yang telah diperoleh disubkulturkan beberapa kali untuk mendapatkan isolat murni. Patogen yang didapatkan ini akan digunakan sebagai cendawan patogen $R$. microporus dan $P$. noxius pada pengujian antagonisme rizobakteri agen biokontrol.

\section{Pengambilan Sampel Tanah dari Daerah Rizosfer Tanaman Karet untuk Isolat Rizobakteri Kandidat Agens Biokontrol}

Pengambilan sampel tanah dilakukan secara purposive sampling yaitu teknik pengambilan sampel dilakukan secara sengaja (tanpa acak) dan sampel yang diambil memiliki kriteria tertentu yaitu tanah disekitar perakaran tanaman karet yang sehat diantara tanaman karet yang sakit. Sampel didapatkan dari perkebunan karet rakyat desa Lango dan desa Kuta Padang Kecamatan Pante Ceureumen Aceh Barat.

Kelompok kandidat agen tersebut diisolasi dari tanah rizosfer tanaman karet pada kedalaman 0-20 cm dari setiap sampel tanaman karet. Pada setiap sampel diambil $1 \mathrm{~kg}$ tanah dan kemudian contoh tanah tersebut dicampur hingga homogen dan diberi label. Tanah

Eksplorasi Rizobakteri Indigenous Dan Uji Antagonis Terhadap Patogen Rigidoporus microporus Dan Phellinus noxius Pada Tanaman Karet (Hevea brasiliensis) Secara In Vitro (Murtadha, M. Abduh Ulim, 
contoh komposit ini dikering angin selama satu hari dan disaring dengan saringan 9 mesh. Selanjutnya tanah tersebut dibawa ke laboratorium untuk diisolasi.

\section{Isolasi Kandidat Agens Biokontrol Rizobakteri Antagonis}

Isolasi rizobakteri dari tanah dilakukan dengan cara pengenceran berseri. Sebelum pengenceran dilakukan, disiapkan satu tabung reaksi berisi $10 \mathrm{ml}$ aquadest steril dan 1 gram sampel tanah yang disebut sebagai biang. Kemudian disiapkan 8 buah tabung reaksi yang berisi aquadest steril sebanyak $9 \mathrm{ml} /$ tabung. Kemudian tabung reaksi yang berisi tanah yang sudah disiapkan dishaker dengan vortex hingga homogen, dari tabung reaksi tersebut diambil $1 \mathrm{ml}$ suspensi tanah dan dimasukkan ke dalam tabung reaksi pertama secara aseptis, tabung reaksi pertama yang ditambahkan $1 \mathrm{ml}$ suspensi tanah kemudian disebut pengenceran 10-1, setelah suspensi dimasukkan lalu dishaker dengan vortex hingga homogen. Diambil $1 \mathrm{ml}$ suspensi dari tabung pengenceran pertama (10-1) dengan pipet ukur kemudian dimasukkan ke tabung reaksi kedua secara aseptis yang kemudian disebut sebagai pengenceran 10-2. Pemindahan suspensi dilanjutkan hingga sampai tingkat pengenceran kedelapan 10-8. Kemudian suspensi pengenceran 10-4, 10-5, 10-6, 10-7, dan 10-8 diambil sebanyak $0.1 \mathrm{ml}$ dan dituang pada media Nutrient Agar (NA) di dalam cawan petri. Koloni masing-masing bakteri yang tumbuh kemudian disubkulturkan beberapa kali untuk mendapatkan isolat murni.

\section{Uji Daya Hambat Rizobakteri Agens Biokontrol Terhadap Pertumbuhan Koloni Patogen (Seleksi Tahap Awal)}

Rizobakteri yang telah berhasil diisolasi kemudian diseleksi tahap awal, seleksi tahap awal ini dilakukan untuk menguji potensinya dalam menghambat pertumbuhan patogen JAC dan JAP, seleksi tahap awal ini dilakukan pada media PDA dengan meletakkan potongan patogen berukuran $0,5 \mathrm{~cm}$ ditengah cawan petri dan meletakkan 4 isolat rizobakteri berjarak $2,25 \mathrm{~cm}$ dengan isolat patogen.

Rizobakteri yang tumbuh paling awal, ukuran koloni besar, warna dan bentuknya jelas, serta membentuk zona hambatan antar rizobakteri dengan patogen di sekitarnya merupakan kriteria isolat kandidat agen biokontrol. Rizobakteri yang sesuai dengan kriteria yang didapatkan selanjutnya akan diuji antagonismenya dengan cara kultur ganda.

\section{Uji Antagonis Rizobakteri Terhadap Patogen JAC dan JAP}

Rizobakteri kandidat agen biokontrol hasil isolasi yang telah diseleksi, dilakukan pengujian kemampuan antagonismenya melawan patogen JAC dan JAP menggunakan teknik kultur ganda. Pengujian dilakukan pada media PDA dalam cawan petri berdiameter $9 \mathrm{~cm}$ dengan cara menempatkan potongan kecil patogen (ukuran $0.5 \mathrm{~cm}$ ) dan rizobakteria antagonis umur 4 hari. Jarak antara titik inokulasi patogen dan rizobakteri antagonis $3 \mathrm{~cm}$ Pengujian diinkubasikan pada temperatur ruangan $\left(28-29^{\circ} \mathrm{C}\right)$, selanjutnya diamati setiap hari hingga 7 hari. Pengamatan penghambatan dilakukan dengan mengukur jarak antara tepi koloni patogen dan rizobakteri antagonis. Pengukuran dilakukan pada saat jari-jari koloni patogen mencapai tepi cawan petri.

\section{Pengamatan}

\section{Persentase Penghambatan Pertumbuhan Koloni Patogen}

Penentuan persentase penghambatan pertumbuhan jari-jari patogen dilakukan untuk setiap isolat. Pengukuran persentase penghambatan pertumbuhan patogen dilakukan menggunakan rumus Soytong, 1988 sebagai berikut : 
Keteraangan :

$$
\mathbf{P P}=\frac{R 1-R 2}{R 1} \times 100 \%
$$

PP = Persentase Penghambatan Pertumbuhan Koloni Patogen

R1 = Jari-Jari Koloni Patogen Tumbuh Menjauhi Agens Antagonis $(\mathrm{Cm})$

R2 = Jari-Jari Koloni Patogen Tumbuh Ke Arah Agens Antagonis (Cm)

Penilaian aktivitas antagonisme rizobakteri ditentukan berdasarkan skala penghambatan yaitu berdasarkan skala persentase penghambatan pertumbuhan koloni sebagai berikut: aktivitas sangat tinggi $(++++=>75 \mathrm{DH})$, aktivitas tinggi $(+++=61-75 \mathrm{DH})$, aktivitas sedang $(++=51$ $60 \mathrm{DH})$, aktivitas rendah $(+=<50 \mathrm{DH})$ dan tidak ada aktivitas $(-)$.

\section{Laju Penghambat Pertumbuhan Koloni Patogen}

Laju penghambatan pertumbuhan koloni patogen dinyatakan dalam satuan $\mathrm{mm} / \mathrm{hari}$ pengamatan dilakukan selama 7 x 24 jam. Pengukuran dilakukan menggunakan rumus sebagai berikut :

Keterangan :

$$
\mathrm{LPPK}=\int_{7}^{0}\left[\frac{X i-X i-1}{X i}\right]
$$

LPPK = Laju Penghambatan Pertumbuhan Koloni Patogen

$\mathrm{Xi} \quad=$ Panjang diameter koloni patogen pada pengamatan ke-i

$\mathrm{Ti} \quad=$ Waktu Pengamatan dinyatakan dalam hari

\section{Analisa Statistik}

Apabila hasil analisis ragam terdapat pengaruh perlakuan secara nyata pada taraf 5\%, maka dilakukan uji lanjutan terhadap nilai rata-rata perlakuan untuk mengetahui perbedaan antar taraf perlakuan dengan menggunakan prosedur Uji Beda Nyata Jujur (BNJ).

\section{HASIL DAN PEMBAHASAN}

Isolat rizobakteri yang diisolasi dari tanah rizosfer tanaman karet sehat diantara tanaman yang sakit diambil diperkebunan milik warga pada dua lokasi yaitu Desa Lango dan Desa Kuta Padang, Kecamatan Pante Ceureumen, Kabupaten Aceh Barat.

Tanah dari kedua desa tersebut dilakukan pengenceran berseri dan penanaman suspensi tanah pengenceran pada media NA, setelah rizobakteri tumbuh pada media NA kemudian dimurnikan beberapa kali untuk mendapatkan isolat rizobakteri yang murni. Isolat rizobakteri yang sudah murni didapatkan sebanyak 78 isolat, yang mana Desa Lango didapatkan sebanyak 40 isolat rizobakteri dan diberi kode dengan nama isolat (DLG), dan Desa Kuta Padang sebanyak 38 isolat rizobakteri dan diberi kode dengan nama isolat (DKP). Isolat-isolat rizobakteri hasil isolat dari rizosfer tanaman karet sehat disajikan pada Tabel 1.

Tabel 1. Isolat-isolat Rizobakteri Hasil Isolasi Dari Rizosfer pada Tanaman Karet

\begin{tabular}{llllll}
\hline \multicolumn{2}{l}{ Rizobakteri Desa Pango } & \multicolumn{4}{l}{ Rizobakteri Desa Kuta Padang } \\
\hline PNG 4/1 & PNG 5/6 & PNG 6/9 & KTP 4/1 & KTP 6/4 & KTP 7/8 \\
PNG 4/2 & PNG 5/7 & PNG 7/1 & KTP 4/2 & KTP 6/5 & KTP 7/9 \\
PNG 4/3 & PNG 5/8 & PNG 7/2 & KTP 4/3 & KTP 6/6 & KTP 7/10 \\
PNG 4/4 & PNG 5/9 & PNG 7/3 & KTP 4/4 & KTP 6/7 & KTP 8/1 \\
PNG 4/5 & PNG 5/10 & PNG 7/4 & KTP 5/1 & KTP 6/8 & KTP 8/2 \\
PNG 4/6 & PNG 6/1 & PNG 7/5 & KTP 5/2 & KTP 6/9 & KTP 8/3 \\
PNG 4/7 & PNG 6/2 & PNG 7/6 & KTP 5/3 & KTP 7/1 & KTP 8/4
\end{tabular}

Eksplorasi Rizobakteri Indigenous Dan Uji Antagonis Terhadap Patogen Rigidoporus microporus Dan Phellinus noxius Pada Tanaman Karet (Hevea brasiliensis) Secara In Vitro (Murtadha, M. Abduh Ulim, 


\begin{tabular}{llllll} 
PNG 4/8 & PNG 6/3 & PNG 8/1 & KTP 5/4 & KTP 7/2 & KTP 8/5 \\
PNG 4/9 & PNG 6/4 & PNG 8/2 & KTP 5/5 & KTP 7/3 & KTP 8/6 \\
PNG 5/1 & PNG 6/5 & PNG 8/3 & KTP 5/6 & KTP 7/4 & KTP 8/7 \\
PNG 5/2 & PNG 6/6 & PNG 8/4 & KTP 6/1 & KTP 7/5 & KTP 8/8 \\
PNG 5/3 & PNG 6/7 & PNG 8/5 & KTP 6/2 & KTP 7/6 & KTP 8/9 \\
PNG 5/4 & PNG 6/8 & PNG 8/6 & KTP 6/3 & KTP 7/7 & \\
PNG 5/5 & & & & & \\
\hline
\end{tabular}

Keterangan : DLG $=$ Desa Lango, DKP $=$ Desa Kuta Padang

Seleksi tahap awal dilakukan pada isolat murni rizobakteri sebanyak 78 isolat untuk melihat potensinya sebagai agen biokontrol yang diuji dengan cendawan patogen $R$. microporus dan $P$. noxius dari hasil uji tahap awal didapatkan sebanyak 15 isolat rizobakteri yang berpotensi sebagai kandidat agen biokontrol dalam menekan pertumbuhan koloni patogen. Sebanyak 15 isolat rizobakteri yang masuk dalam ktriteria tersubut kemudian diuji kemampuan antagonismenya dengan cendawan patogen $R$. microporus dan $P$. noxius dengan teknik kultur ganda.

Rizobakteri adalah sekumpulan bakteri yang aktif disekitaran rhizosfer tanaman, isolat rizobakteri memiliki keefektifan dalam mencegah perkembangan koloni cendawan yang memberi efek menguntungkan bagi perakaran tanaman. Secara umum, mekanisme Agen antagonis dalam menghambat pertumbuhan patogen meliputi kompetisi ruang dan nutrisi, memproduksi senyawa allelokimia yang bersifat menghambat patogen, dan menginduksi ketahanan sistemik tanaman inang (Compant et al. 2005).

Isolat rizobakteri sebanyak 15 yang sudah diseleksi pada uji tahap awal kemudian diuji untuk melihat kemampuan antagonisnya dalam menekan pertumbuhan koloni cendawan patogen $R$. microporus dan $P$. noxius tanaman karet secara in vitro dengan teknik kultur ganda. Hasil uji $\mathrm{F}$ pada analisis ragam menunjukan bahwa perlakuan isolat rizobakteri berpengaruh sangat nyata dalam menekan pertumbuhan koloni cendawan patogen $R$. microporus dan patogen $P$. noxius, hasil evaluasi daya hambat rizobakteri terhadap koloni patogen disajikan pada tabel 2, dan 3 .

Tabel 2. Rata-rata Persentase (\%) Daya Hambat isolat Rizobakteri Agen Biokontrol terhadap Pertumbuhan Koloni Patogen pada Tanaman Karet Secara In Vitro

\begin{tabular}{lll}
\hline $\begin{array}{l}\text { Rizobakteri Agen } \\
\text { Biokontrol }\end{array}$ & \multicolumn{2}{c}{ Daya Hambat terhadap Patogen (\%) } \\
\cline { 2 - 3 } DLG 4/1 & Rigidoporus microporus & Phellinus noxius \\
\hline DLG 4/6 & $55,66 \mathrm{~d}$ & $16,66 \mathrm{ab}$ \\
DLG 4/7 & $63,33 \mathrm{~d}$ & $23,33 \mathrm{bc}$ \\
DLG 5/1 & $59,99 \mathrm{~cd}$ & $16,66 \mathrm{ab}$ \\
DLG 5/3 & $68,33 \mathrm{~d}$ & $60,33 \mathrm{i}$ \\
DLG 5/8 & $60,00 \mathrm{~cd}$ & $38,33 \mathrm{fg}$ \\
DLG 6/4 & $13,33 \mathrm{a}$ & $36,33 \mathrm{ef}$ \\
DLG 7/1 & $41,66 \mathrm{~b}$ & $33,33 \mathrm{def}$ \\
DLG 7/4 & $16,66 \mathrm{a}$ & $30,00 \mathrm{cde}$ \\
DLG 8/2 & $56,66 \mathrm{~cd}$ & $35,41 \mathrm{ef}$ \\
DKP 4/1 & $14,44 \mathrm{a}$ & $48,33 \mathrm{~h}$ \\
DKP 4/2 & $50,00 \mathrm{bc}$ & $15,00 \mathrm{a}$ \\
DKP 6/3 & $58,33 \mathrm{~cd}$ & $26,66 \mathrm{~cd}$ \\
& & $52,50 \mathrm{hi}$
\end{tabular}

Eksplorasi Rizobakteri Indigenous Dan Uji Antagonis Terhadap Patogen Rigidoporus microporus Dan Phellinus noxius Pada Tanaman Karet (Hevea brasiliensis) Secara In Vitro (Murtadha, M. Abduh Ulim, 


\begin{tabular}{lll} 
DKP 6/4 & $20,00 \mathrm{a}$ & $46,33 \mathrm{gh}$ \\
DKP $8 / 9$ & $18,26 \mathrm{a}$ & $16,66 \mathrm{ab}$ \\
BNJ 0,05 & 13,07 & 8,02 \\
\hline
\end{tabular}

Keterangan : Angka yang diikuti oleh huruf yang sama pada kolom yang sama berbeda tidak nyata pada Uji Beda Nyata jujur (BNJ) $\alpha=0,05$

Tabel 2. menunjukkan bahwa pada uji daya hambat patogen $R$. microporus isolat rizobakteri yang memiliki persentase daya hambat terbaik terdapat 3 isolat yaitu isolat DLG5/3, DLG4/1 dan DLG4/7 yang berbeda tidak nyata dengan 5 isolat rizobakteri lainnya, tetapi berbeda nyata dengan 7 isolat yaitu isolat DLG6/4, DKP4/1, DLG7/4, DKP8/9, DKP6/4, DLG7/1 dan DKP 4/2. Pada uji daya hambat pada patogen P. noxius isolat rizobakteri yang memiliki persentase daya hambat terbaik terdapat satu isolat yaitu isolat DLG5/1 yang berbeda tidak nyata dengan satu isolat rizobakteri lainnya, tetapi berbeda nyata dengan 13 isolat yaitu isolat DKP4/1, DLG4/1, DLG4/7, DKP8/9, DLG4/6, DKP4/2, DLG7/1, DLG6/4, DLG7/4, DLG5/8, DLG5/3, DLG58/2, dan DKP6/4.

Hasil penelitian Muharmi dan Widjajanti (2011) menunjukkan bakteri Bacillus sp dan B.apiarus yang diisolasi dari rizosfer tanaman karet bersifat antagonis terhadap $R$. microporus dengan menghasilkan enzim kitinolitik.

Tabel 3. Aktivitas Daya Hambat Isolat Rizobakteri Kandidat Agen Biokontrol terhadap Pertumbuhan Koloni Patogen pada Tanaman Karet

\begin{tabular}{lll}
\hline Rizobakteri Agen & \multicolumn{2}{c}{ Aktivitas Daya Hambat terhadap Patogen } \\
\cline { 2 - 3 } & Rigidoporus microporus & Phellinus noxius \\
\hline DLG 4/1 & +++ & + \\
DLG 4/6 & ++ & + \\
DLG 4/7 & +++ & + \\
DLG 5/1 & ++ & ++ \\
DLG 5/3 & +++ & + \\
DLG 5/8 & ++ & + \\
DLG 6/4 & + & + \\
DLG 7/1 & + & + \\
DLG 7/4 & + & + \\
DLG 8/2 & ++ & + \\
DKP 4/1 & + & + \\
DKP 4/2 & + & + \\
DKP 6/3 & ++ & ++ \\
DKP 6/4 & + & + \\
DKP 8/9 & + & + \\
\hline Keterangan: & aktivitas sangat tinggi (+++++ = 75\% DH), aktivitas tinggi (++++ & $+61-75 \%$ DH), aktivitas sedang \\
& $(++=51-60 \%$ DH), aktivitas rendah (+ =<50\% DH) dan tidak ada aktivitas (-)
\end{tabular}

Tabel 3. menunjukkan bahwa Isolat rizobakteri pada patogen $R$. microporus dengan aktivitas penghambat tinggi $(61-75 \% \mathrm{DH})$ yaitu $\mathrm{DLG} 5 / 3=68,3 \%, \mathrm{DLG} 4 / 1=66,6 \%$, dan DLG4/7 $=63,3 \%$, terdapat lima isolat rizobakteri dengan aktivitas penghambat sedang (51$60 \% \mathrm{DH})$, yaitu DLG5/8 $=60,0 \%, \mathrm{DLG} 5 / 1=59,9 \%$, DKP6/3 $=58,3 \%$, DLG $8 / 2=56,6 \%$, $\mathrm{DLG} 4 / 6=55,5 \%$. Isolat dengan daya hambat rendah terdapat pada 7 isolat rizobakteri lainnya dengan aktivitas penghambat $(\leq 50 \% \mathrm{DH})$. Isolat rizobakteri pada patogen $P$. noxius dengan aktivitas penghambat sedang $(51-60 \%$ DH) yaitu DLG5/1=60,3\% dan DKP6/3 $=52,5 \%$.

Eksplorasi Rizobakteri Indigenous Dan Uji Antagonis Terhadap Patogen Rigidoporus microporus Dan Phellinus noxius Pada Tanaman Karet (Hevea brasiliensis) Secara In Vitro (Murtadha, M. Abduh Ulim, 
Isolat dengan daya hambat rendah terdapat pada 13 isolat rizobakteri lainnya dengan aktivitas penghambat $(\leq 50 \% \mathrm{DH})$.

Keberhasilan pengendalian hayati terhadap penyakit tanaman ditentukan oleh mekanisme penghambat dari agensia hayatinya. Siderofor, antibiosis, persaingan, mikoparasitisme, PGPR, ketahanan terimbas, enzim, dan toksin merupakan mekasisme penghambatan yang umumnya dijumpai pada agensia hayati. Hasil penelitian Hardiyanti (2017) menunjukkan isolat bakteri MR3 memiliki daya hambat sebesar $62,5 \%$ dan isolat bakteri ME8 memiliki daya hambat sebesar 70,0\% dalam menghambat pertumbuhan $R$. microporus. Kedua isolat bakteri tersebut memiliki mekanisme pengendalian patogen yang berbeda-beda, isolat bakteri MR3 menghasilkan senyawa allelokimia dalam menekan pertumbuhan $R$. microporus, sedangkan mekanisme kompetisi ruang dan nutrisi dimiliki pada isolat bakteri ME8.

Isolat rizobakteri juga memiliki laju penghambatan terhadap pertumbuhan koloni cendawan yang berbeda-beda terhadap pertumbuhan patogen $R$. microporus dan $P$. noxius. yang diukur setiap harinya. Analisis ragam uji $F$ menunjukan hasil laju penghambat isolat rizobakteri berpengaruh sangat nyata terhadap kedua patogen diuji. Laju penghambat isolat rizobakteri kandidat Agen biokontrol terhadap pertumbuhan koloni cendawan patogen $R$. microporus dan $P$. noxius. disajikan pada Tabel 4.

Tabel 4. Laju Penghambat Isolat Rizobakteri Kadidat Agen Biokontrol terhadap Pertumbuhan Koloni Patogen pada Tanaman Karet

\begin{tabular}{lll}
\hline \multirow{2}{*}{ Rizobakteri Agen Biokontrol } & \multicolumn{2}{c}{ Laju Penghambatan Rizobakteri (mm/hari) } \\
\cline { 2 - 3 } & Rigidoporus microporus & Phellinus noxius \\
\hline DLG 4/1 & $10,00 \mathrm{a}$ & $12,05 \mathrm{~b}$ \\
DLG 4/6 & $12,50 \mathrm{a}$ & $10,10 \mathrm{~b}$ \\
DLG 4/7 & $11,00 \mathrm{a}$ & $11,05 \mathrm{~b}$ \\
DLG 5/1 & $11,17 \mathrm{a}$ & $5,25 \mathrm{a}$ \\
DLG 5/3 & $10.00 \mathrm{a}$ & $10,20 \mathrm{~b}$ \\
DLG 5/8 & $10,50 \mathrm{a}$ & $10,07 \mathrm{~b}$ \\
DLG 6/4 & $20,33 \mathrm{~d}$ & $11,23 \mathrm{~b}$ \\
DLG 7/1 & $11,50 \mathrm{a}$ & $11,80 \mathrm{~b}$ \\
DLG 7/4 & $19,17 \mathrm{~cd}$ & $5,00 \mathrm{a}$ \\
DLG 8/2 & $16,25 \mathrm{bc}$ & $9,90 \mathrm{~b}$ \\
DKP 4/1 & $20,33 \mathrm{~d}$ & $10,17 \mathrm{~b}$ \\
DKP 4/2 & $13,50 \mathrm{ab}$ & $10,33 \mathrm{~b}$ \\
DKP 6/3 & $11,75 \mathrm{a}$ & $5,85 \mathrm{a}$ \\
DKP 6/4 & $19,75 \mathrm{~cd}$ & $10,88 \mathrm{~b}$ \\
DKP 8/9 & $19,67 \mathrm{~cd}$ & $11,80 \mathrm{~b}$ \\
BNJ 0,05 & 3,57 & 2,35 \\
\hline K
\end{tabular}

Keterangan : Angka yang diikuti oleh huruf yang sama pada kolom yang sama berbeda tidak nyata pada Uji Beda Nyata jujur (BNJ) $\alpha=0,05$

Tabel 4. Menunjukkan bahwa laju penghambatan isolat rizobakteri yang paling baik pada patogen $R$. microporus yaitu isolat DLG6/4 dan DKP4/1 dengan nilai rerata laju penghambatan $20,33 \mathrm{~mm} /$ hari yang berbeda tidak nyata dengan tiga isolat rizobakteri lainnya, tetapi berbeda nyata dengan sepuluh isolat yaitu isolat DLG4/1, DLG5/3, DLG5/8, DLG4/7, DLG5/1, DLG7/1, DKP6/3, DLG4/6, DKP4/2, dan DLG8/2. Pada patogen $P$. noxius 
menunjukan bahwa laju penghambatan isolat rizobakteri yang paling tinggi yaitu isolat DLG4/1 dengan nilai laju penghambatan $12,05 \mathrm{~mm} /$ hari yang berbeda tidak nyata dangan sebelas isolat rizobakteri lainnya, tetapi berbeda nyata dengan tiga isolat yaitu isolat DLG7/4, DLG5/1 dan DKP6/3

Muhami dan Widjajanti (2011), berhasil mengisolasi bakteri kitinolitik dari rizosfir tanaman karet diperoleh 11 isolat bakteri kitinolitik, dan hanya 4 isolat yang menunjukkan adanya aktivitas kitinase yaitu BRK5, BRK6, BRK7, BRK11. Bakteri isolat BRK5 dan BRK7 yang diuji secara in vitro mampu menghambat pertumbuhan $R$. microporus. Potensi isolat bakteri kitinolitik dalam menghasilkan enzim kitinase dalam menghambat pertumbuhan jamur akar putih. Mekanisme kerja dari enzim kitinase yaitu dapat mendegradasi dinding sel jamur, disebabkan dinding sel dari jamur memiliki kitin.

Metode seleksi awal merupakan salah satu untuk menentukan isolat rizobakteri yang berpotensi sebagai agensia pengendalian penyakit tanaman dengan cara metode uji daya hambat isolat rizobakteri terhadap patogen penyakit. Isolat rizobakteri yang memiliki karakter fisiologis dan biokimiawi berhubungan dengan kemampuannya sebagai agen antagonis patogen (biopestisida) dalam mensekresikan enzim ekstraseluler (selulase, kitinase, dan protease), memproduksi senyawa $\mathrm{HCN}$, serta kemampuannya sebagai pemacu pertumbuhan tanaman, dalam melarutkan fosfat dan memproduksi hormon IAA (Sutariati dan Wahab, 2010).

\section{KESIMPULAN DAN SARAN}

Isolat rizobakteri yang mampu menghambat pertumbuhan koloni cendawan patogen $R$. microporus yaitu isolat DLG5/3 dengan persentase penghambatan 68,33\%, DLG4/1 dengan persentase penghambatan $66,66 \%$ dan DLG4/7 dengan persentase penghambatan $63,33 \%$. Untuk patogen $P$. noxius persentase penghambatan terbaik yaitu isolat DLG5/1 dengan persentase penghambatan $60,33 \%$, dan DKP6/3 dengan persentase penghambatan $52,50 \%$. Isolat rizobakteri yang memiliki laju penghambatan terbaik pada koloni patogen $R$. microporus yaitu isolat DLG6/4 dan DKP4/1 dengan nilai rerata laju penghambatan 20,33 $\mathrm{mm} /$ hari. Sedangkan pada koloni patogen $P$. noxius isolat rizobakteri yang paling baik yaitu isolat DLG4/1 dengan nilai laju penghambatan 12,05 $\mathrm{mm} / \mathrm{hari}$.

\section{DAFTAR PUSTAKA (format yang dipergunakan APA \& Harvard)}

Agarwal, V.K., J.B. Sinclair. 1987. Principle of seed Pathology. CRC Press, Inc. Boca Raton, Florida.

Brooks, G.F., K.C. Carroll, J.S. Butel dan S.A. Morse. 2007. Medical Microbiology. $\quad 24^{\text {th }}$ ed United States of America: The McGraw Hill Companies, Inc.

Compant, S., B. Duffy, J. Nowak, C. Clement dan E.A. Barkal. 2005. Use of plant growthpromoting bacteria for biocontrol of plant disease: principle, mechanisms of action, and future prospects. Appl Environ Microbiol. 71: 4951-4959.

Diekmann, M. 1993. Seedborne Diseases in Seed Production. International Center of Agricultural Reseacrh in thr Dry Areas (ICARDA). Aleppo, Syiria.

Direktorat Jenderal Perkebunan. 2016. Stasistik Perkebunan Indonesia Komoditi Karet 20152017. Kementerian Pertanian. http://ditjenbun.pertanian.go.id. Diakses tanggal: 05 september 2017.

Gao, F. K., Ch. Dai dan X. Z. Liu. 2010. Mechanisms of fungal endophytes in plant protection against pathogens. Africa Journal of Microbiology Research. 4: 1346-1351

Eksplorasi Rizobakteri Indigenous Dan Uji Antagonis Terhadap Patogen Rigidoporus microporus Dan Phellinus noxius Pada Tanaman Karet (Hevea brasiliensis) Secara In Vitro (Murtadha, M. Abduh Ulim, 
Hardiyanti, S. 2017 Mikrob Rizosfer Dan Endofit Jaringan Akar Tanaman Karet Sebagai Agen Hayati Penyakit Akar Puth (Rigidoporus lignosus (klotzsch) imazeki). Tesis Pascasarjana. IPB

Muharni dan H. Widjajanti. 2011. Skrining bakteri kitinolitik antagonis terhadap pertumbuhan jamur akar putih Rigidoporus lignosus dari rizosfir tanaman karet. J Penel Sains. 14: 14112-14151.

Nasrun, Nurmansyah, Burhanuddin dan Zulkarnain. 2012. Pemanfaatan formulasi pestisida nabati dan Agenia hayati untuk mengendalikan penyakit jamur akar putih pada karet. Pusat dan Pengembangan Perkebunan Badan Penelitian dan Pengembangan Pertanian Kementrian Pertanian. Jakarta.

Semangun, H. 2000. Penyakit-Penyakit Tanaman Perkebunan di Indonesia. Gajah Mada University Press. Yogyakarta

Siagian, N. 1995. Upaya mempertahankan kerapatan tanaman karet. Warta Pusat Penelitian Karet. 14: 53-61.

Situmorang, A. 2004. Status dan Manajemen Pengendalian Jamur Akar Putih di Perkebunan Karet. Prosiding Pertemuan Teknis. Pusat Penelitian Karet, Balai Penelitian Sembawa. 66-86.

Situmorang, A., H. Suryaningtyas, and S. Pawirosoemardjo. 2007. Current status of white root disease (Rigidoporus microporus) and the disease control management in rubber plantation of Indonesia. Proceedings. International Workshop on White Root Disease of Hevea Rubber.Salatiga, 28th th - 29 November. International Rubber Research Development Board.: 27 - 33.

Supriadi, E. M., D. Adhi, S. Wahyuno, N. Rahayuningsih, Karyani dan M. Dahsyat. 2004. Brown root rot disease ofcashew in West Nusa Tenggara :Distribution and its causal organism.Indonesian Journal of Agricultural Science. 51:32-36

Sutariati, G.A.K dan A. Wahab, 2010. Isolasi dan uji kemampuan Rizobakteri indigenous sebagai Agenia hayati pengendali hayati penyakit pada tanaman cabai. J. Hort., 20: 8695. 